D. A. Coelho*

\title{
SOCIAL, CULTURAL AND WORKING CONDITIONS DETERMINANTS OF FATAL AND NON-FATAL OCCUPATIONAL ACCIDENTS IN EUROPE
}

UDK 614.8:331.45](4)

RECEIVED: 2019-06-04

ACCEPTED: 2020-03-02

This work is licensed under a Creative

Commons Attribution 4.0 International License

\begin{abstract}
SUMMARY: The determinants of occupational accidents from a social, cultural and a working condi-tions combined perspective are unveiled considering the level of analysis of the European nation. Fatal and non-fatal work accidents in 2014, collected and provided by Eurostat, are correlated with country by country results of the 7th European Social Survey (ESS) (2014 data). This informs on social deter-minants of work accidents. National Dimensions of Culture proposed by Gert Hofstede are correlated with country by country results of the ESS informing on cultural determinants of the European Social Dimensions reported on the ESS. Moreover, considering data from the 6th European Working Condi-tions Survey (2015 data), working conditions, on a country by country basis as well, are further consid-ered and analyzed from the perspective of fatal and nonfatal accidents and from the perspective of social and cultural dimensions. This multiple pronged study of association unveils interesting associa-tions between fatal and non-fatal work accidents and working conditions, as well as between fatal and non-fatal work accidents and social and cultural dimensions, and, between social and cultural dimen-sions and working conditions, taking the European country as a unit of analysis. The findings shed light on the interconnectedness of the distinct domains under study, as well as informing policy development towards creating tailor made approaches suiting each country reality within the countries encompassed in the analysis.
\end{abstract}

Key words: Social Dimensions; Culture; Occupational Health and Safety; Accidents at Work; International Analysis

\section{INTRODUCTION}

Humanitarian and economic considerations alike prompt the need to improve working conditions, which is a collective concern. A safe and healthy working environment is an essential element of the quality of work. A territory populated by more than five hundred million people, the European continent boasts high levels of diversity, which has been studied and analyzed in several dimensions, cross-sectionally and longitudinally.

*Denis A. Coelho, (denis.coelho@ju.se, dac@ubi.pt, denis.a.coelho@gmail.com), Human Factors and Ergonomics Group, Dept. of Supply Chain and Operations Management, School of Engineering, Jön-köping university, Jönköping, Sweden, Human Technology Group, Dept. of Electromechanical Engi-neering and Centre for Mechanical and Aerospace Science and Technologies, Universidade da Beira Interior, Covilhã, Portugal.
European Union institutions have been carrying out themselves, and, or, sponsoring academic institutions to do the analysis and monitoring of a great set of indicators across the continent, including social dimensions, working conditions and fatal and non-fatal work injuries.

In an effort to continuously reduce work accidents, understanding their social and working conditions determinants may shed light on the need for particular policy measures aiming at improving social dimensions and working conditions across the continent. The study reported in this paper aims providing a contribution to the understanding of the association of social factors and working conditions with fatal and non-fatal accidents across Europe. In particular, the study's 
objective is to analyze the determinants of fatal and non-fatal accidents at work from a social, cultural and working conditions combined perspective, considering the level of analysis of the nation. In this paper, the most recent EUROSTAT statistics of EU fatal and non-fatal accidents at work are first presented and then correlated (with the assistance of IBM SPSSS v.23) with selected country by country re-sults of the 7 th European Social Survey (2014 data) (ESS7, 2014). This informs on social determi-nants (selected European Social Dimensions reported on the 2014 ESS - Round 7) of fatal and non-fatal accidents at work. The National Dimensions of Culture proposed by Gert Hofstede are first pre-sented and then correlated (with the assistance of IBM SPSSS v.23) with selected country by country results of the 7th European Social Survey (2014 data). This informs on cultural determinants of selected European Social Dimensions reported on the 2014 ESS (Round 7). Additionally, consider-ing data from the 6th European Working Conditions Survey (2015 data) (6 ${ }^{\text {th }}$ EWCS, 2015), selected aspects of working conditions, on a country by country basis as well, are further considered and analyzed from the perspective of social and cultural dimensions and from the perspective of accidents at work, taking the European country as a unit of analysis. The findings shed light on the interconnectedness of the distinct domains under study, as well as informing policy development towards creating tailor made approaches suiting each particular country rea- lity within the sample of countries encompassed in the analysis.

\section{FATAL AND NON-FATAL ACCIDENTS AT WORK (2014 DATA)}

Non-fatal and fatal accidents at work in the European Union (EU) are collected within the frame-work of the European statistics on accidents at work (ESAW) administrative data collection. In ESAW methodology an accident at work is defined as a discrete occurrence during the course of work which leads to physical or mental harm. Fatal accidents at work are those that lead to the death of the victim within one year. Nonfatal accidents at work collected within ESAW are those that imply at least four full calendar days of absence from work (they are sometimes also called 'serious accidents at work'). Non-fatal accidents at work often involve considerable harm for the workers concerned and their families and they have the potential to force people, for example, to live with a permanent disability, to leave the labor market, or to change job; indeed, they result in a considerable number of days of work being lost (EUROSTAT, 2017).

The most recent statistics of EU fatal and nonfatal accidents at work available from EUROSTAT are shown on Table 1. They are depicted both in absolute terms and as per capita values, considering the total population of the country (as of January $1^{\text {st }} 2015$, according to EUROSTAT (2017b). 
Table 1. Fatal and Non-Fatal Accidents at Work data from 2014 (EUROSTAT) for 29 European countries (2017c) (per capita values obtained by combining data from EUROSTAT, 2017; 2017b)

Tablica 1. Podatci o nesrećama na radu sa smrtnim i nesmrtnim posljedicama iz 2014. (EUROSTAT) za 29 europskih zemalja (2017.c); (vrijednosti po stanovniku dobivene su kombiniranjem podataka EUROSTAT-a, 2017; 2017.b)

\begin{tabular}{|c|c|c|c|c|}
\hline Country & $\begin{array}{l}\text { Fatal accidents } \\
\text { at work }\end{array}$ & $\begin{array}{l}\text { Fatal acc. at work per capita } \\
\text { [/million] }\end{array}$ & $\begin{array}{c}\text { Non-fatal accidents at } \\
\text { work }\end{array}$ & $\begin{array}{l}\text { Non-fatal work acc. } \\
\text { per capita [/thousand] }\end{array}$ \\
\hline Austria & 126 & 14.7 & 65,418 & 7.6 \\
\hline Belgium & 52 & 4.6 & 65,587 & 5.9 \\
\hline Czech Republic & 118 & 11.2 & 42,306 & 4.0 \\
\hline Denmark & 38 & 6.7 & 54,157 & 9.6 \\
\hline Estonia & 16 & 12.2 & 6,288 & 4.8 \\
\hline Finland & 22 & 4.0 & 47,432 & 8.7 \\
\hline France & 589 & 8.9 & 724,662 & 10.9 \\
\hline Germany & 500 & 6.2 & 847,370 & 10.4 \\
\hline Hungary & 81 & 8.2 & 19,491 & 2.0 \\
\hline Ireland & 47 & 10.2 & 18,115 & 3.9 \\
\hline Lithuania & 55 & 18.8 & 3,120 & 1.1 \\
\hline Netherlands & 45 & 2.7 & 87,964 & 5.2 \\
\hline Norway & 61 & 11.8 & 10,108 & 2.0 \\
\hline Poland & 263 & 6.9 & 76,274 & 2.0 \\
\hline Portugal & 160 & 15.4 & 130,153 & 12.5 \\
\hline Slovenia & 25 & 12.1 & 12,314 & 6.0 \\
\hline Spain & 280 & 6.0 & 387,439 & 8.3 \\
\hline Sweden & 40 & 4.1 & 35,296 & 3.6 \\
\hline Switzerland & 74 & 9.0 & 86,346 & 10.5 \\
\hline United Kingdom & 111 & 1.7 & 244,948 & 3.8 \\
\hline Bulgaria & 117 & 16.2 & 2,246 & 0.3 \\
\hline Croatia & 26 & 6.2 & 11,669 & 2.8 \\
\hline Greece & 28 & 2.6 & 3,410 & 0.3 \\
\hline Italy & 522 & 8.6 & 313,312 & 5.2 \\
\hline Latvia & 41 & 20.6 & 1,725 & 0.9 \\
\hline Luxembourg & 10 & 17.8 & 7,183 & 12.8 \\
\hline Malta & 4 & 9.3 & 2,632 & 6.1 \\
\hline Romania & 272 & 13.7 & 3,396 & 0.2 \\
\hline Slovakia & 40 & 7.4 & 8,552 & 1.6 \\
\hline
\end{tabular}




\section{SELECTED DIMENSIONS OF THE EUROPEAN SOCIAL SURVEY (2014 DATA)}

The European Social Survey (ESS) (ESS7, 2014) is an academically driven cross-national survey that has been conducted across Europe since its establishment in 2001. Every two years, face-toface interviews are conducted with newly selected, cross-sectional samples. The survey measures the attitudes, beliefs and behavior patterns of diverse populations in more than thirty nations.

For the purpose of the analysis reported on this paper, a selection was made of 16 indicators extracted from the ESS round 72014 data, using as criteria to extract no more than two questions from each of the core section themes (media and social trust, politics, subjective well-being, gender and house-hold, socio demographics and human values), with the exception of human values, where more variables were extracted, in order to match them with the cultural dimensions presented in section 2. Table 2 depicts the result of the selection. The selection was subjectively carried out by the researcher, based on the perception of the most impactful themes covered in the ESS7 regarding working conditions.

Selected average scores per country were obtained from the dataset (ESS round 7) and are shown in Tables 3 and 4 . In this process, the response scale items were considered in a question by question approach (answer ranges shown to survey respondents are given in the Tables captions).

Table 2. Variables of the ESS round 7 (2014) core questionnaire selected for analysis

Tablica 2. Varijable ESS-a sedme skupine (2014.) iz temeljne ankete korištene u analizi

\begin{tabular}{||l|l||}
\hline \multicolumn{1}{|c|}{ Core Section Theme } & \multicolumn{1}{c|}{ Data/Variables selected } \\
\hline Media and Social Trust & $\begin{array}{l}\text { ppltrst: Most people can be trusted or you can't be too careful } \\
\text { pplhlp: Most of the time people helpful or mostly looking out for themselves }\end{array}$ \\
\hline Politics & $\begin{array}{l}\text { trstlgl: Trust in the legal system } \\
\text { stflife: How satisfied with life as a whole }\end{array}$ \\
\hline Subjective Well-Being & $\begin{array}{l}\text { sclmeet: How often socially meet with friends, relatives or colleagues } \\
\text { health: Subjective general health }\end{array}$ \\
\hline Gender and Household & $\begin{array}{l}\text { gndr: Gender } \\
\text { agea: Age of respondent, calculated }\end{array}$ \\
\hline Socio demographics & $\begin{array}{l}\text { edulvlb: Highest level of education } \\
\text { wrkctra: } \text { Employment contract unlimited or limited duration }\end{array}$ \\
\hline Human Values & $\begin{array}{l}\text { ipeqopt: Important that people are treated equally and have equal opportunities } \\
\text { ipshabt: Important to show abilities and be admired } \\
\text { ipfrule: Important to do what is told and follow rules } \\
\text { impfree: Important to make own decisions and be free } \\
\text { ipadvnt: Important to seek adventures and have an exciting life } \\
\text { imptrad: Important to follow traditions and customs }\end{array}$ \\
\hline
\end{tabular}


Table 3. Part 1 of 2 of selected average scores per country obtained from the dataset (ESS round 7) (legend of headings given in Table 2) (ppltrst scale: 0-You can't be too careful -- 10-Most People can be trusted; pplhlp scale: 0-People mostly look out for themselves -- 10-People mostly try to be helpful; trstlgl scale: 0 -no trust at all -- 10-complete trust; stflife scale: 0-extremely dissatisfied -- 10-extremely satisfied; sclmeet scale: 1-never -- 7-every day; health scale: 1-very good -- 5-very bad) (ESS7, 2014)

Tablica 3. Prvi od dva dijela odabranih prosječnih rezultata po zemljama iz baze podataka (ESS 7) (legenda naslova nalazi se u Tablici 2); (ppltrst skala: 0-Ne možemo biti preoprezni do 10-Većini ljudi možemo vjerovati; pplhlp skala: 0-Većina ljudi brine samo o sebi do 10-Ljudi uglavnom nastoje pomoći; trstlgl skala: 0-Nema povjerenja do 10-Potpuno povjerenje; stflife skala: 0-Iznimno nezadovoljan do 10-Iznimno zadovoljan; sclmeet skala: 1-Nikad do 7-Svaki dan; skala zdravlja: 1-Vrlo dobro do 5 -Vrlo loše); (ESS7, 2014.)

\begin{tabular}{|c|c|c|c|c|c|c|}
\hline Country & ppltrst & pplhlp & trstlgl & stflife & sclmeet & health \\
\hline Austria & 4.968 & 5.081 & 5.638 & 7.380 & 4.867 & 1.979 \\
\hline Belgium & 5.016 & 4.632 & 5.020 & 7.452 & 5.131 & 2.053 \\
\hline Czech Republic & 4.479 & 4.548 & 4.659 & 6.641 & 4.485 & 2.086 \\
\hline Denmark & 6.903 & 6.070 & 7.404 & 8.356 & 5.320 & 1.928 \\
\hline Estonia & 5.574 & 5.015 & 5.215 & 6.401 & 4.180 & 2.563 \\
\hline Finland & 6.739 & 5.971 & 6.758 & 7.922 & 5.014 & 2.187 \\
\hline France & 4.666 & 4.704 & 5.131 & 6.395 & 5.185 & 2.294 \\
\hline Germany & 5.092 & 5.263 & 5.739 & 7.422 & 4.727 & 2.339 \\
\hline Hungary & 4.175 & 4.359 & 4.623 & 5.834 & 3.476 & 2.464 \\
\hline Ireland & 5.128 & 5.847 & 5.291 & 6.943 & 4.526 & 1.859 \\
\hline Israel & 5.153 & 5.032 & 5.554 & 7.376 & 4.626 & 1.925 \\
\hline Lithuania & 4.770 & 4.454 & 4.335 & 5.812 & 4.006 & 2.483 \\
\hline Netherlands & 5.975 & 5.629 & 5.909 & 7.602 & 5.414 & 2.181 \\
\hline Norway & 6.617 & 6.062 & 7.188 & 7.942 & 5.353 & 1.942 \\
\hline Poland & 3.948 & 3.662 & 3.545 & 6.932 & 4.148 & 2.327 \\
\hline Portugal & 3.667 & 3.991 & 3.708 & 5.800 & 5.691 & 2.587 \\
\hline Slovenia & 4.069 & 4.933 & 3.131 & 6.573 & 4.564 & 2.386 \\
\hline Spain & 4.828 & 4.351 & 4.018 & 6.965 & 5.222 & 2.314 \\
\hline Sweden & 6.245 & 6.110 & 6.385 & 7.903 & 5.450 & 1.966 \\
\hline Switzerland & 5.719 & 5.690 & 6.583 & 8.077 & 5.136 & 1.876 \\
\hline United Kingdom & 5.376 & 5.920 & 5.548 & 7.163 & 4.808 & 2.140 \\
\hline
\end{tabular}


Table 4. Part 2 of 2 of selected average scores per country obtained from the dataset (ESS round 7) (legend of headings given in Table 2) (scale: 1-Very much like me - 6-Not like me at all) (ESS7, 2014)

Tablica 4. Drugi dio odabranih prosječnih rezultata po zemljama iz baze podataka ESS7 (legenda naslova nalazi se u Tablici 2); (skala: 1-Vrlo slično meni do 6-Uopće nije slično meni); (ESS7, 2014.)

\begin{tabular}{|c|c|c|c|c|c|c|}
\hline Country & ipeqopt & ipshabt & ipfrule & impfree & ipadvnt & imptrad \\
\hline Austria & 1.952 & 2.967 & 3.141 & 1.933 & 3.903 & 2.565 \\
\hline Belgium & 2.039 & 3.105 & 3.158 & 2.126 & 3.857 & 2.711 \\
\hline Czech Republic & 2.497 & 3.301 & 2.695 & 2.354 & 3.740 & 2.621 \\
\hline Denmark & 2.113 & 3.514 & 2.810 & 2.163 & 3.449 & 2.758 \\
\hline Estonia & 2.364 & 3.573 & 3.328 & 2.266 & 4.106 & 2.926 \\
\hline Finland & 1.947 & 3.836 & 3.018 & 2.142 & 3.890 & 3.031 \\
\hline France & 1.851 & 3.503 & 3.845 & 2.581 & 4.215 & 3.349 \\
\hline Germany & 1.887 & 3.590 & 3.563 & 1.921 & 4.288 & 2.973 \\
\hline Hungary & 2.022 & 2.615 & 3.295 & 2.062 & 3.792 & 2.445 \\
\hline Ireland & 2.075 & 2.884 & 3.122 & 2.212 & 3.666 & 2.581 \\
\hline Israel & 1.974 & 2.374 & 2.724 & 1.953 & 3.565 & 2.453 \\
\hline Lithuania & 2.461 & 3.278 & 3.353 & 2.606 & 3.951 & 2.547 \\
\hline Netherlands & 2.094 & 3.287 & 3.013 & 2.039 & 3.727 & 2.888 \\
\hline Norway & 2.123 & 3.714 & 2.736 & 2.389 & 3.720 & 3.016 \\
\hline Poland & 1.912 & 3.100 & 2.429 & 2.070 & 4.031 & 2.129 \\
\hline Portugal & 2.140 & 3.213 & 3.451 & 2.314 & 4.350 & 2.884 \\
\hline Slovenia & 1.715 & 2.447 & 3.031 & 1.813 & 3.708 & 2.392 \\
\hline Spain & 1.622 & 3.451 & 3.264 & 2.104 & 4.026 & 2.703 \\
\hline Sweden & 1.765 & 3.545 & 3.337 & 2.247 & 3.810 & 3.170 \\
\hline Switzerland & 1.918 & 2.962 & 3.353 & 1.741 & 3.750 & 2.800 \\
\hline United Kingdom & 2.022 & 3.228 & 3.350 & 2.136 & 3.837 & 2.874 \\
\hline
\end{tabular}




\section{HOFSTEDE'S NATIONAL DIMENSIONS OF CULTURE}

The six measures of national cultures, initially identified by Hofstede (1980, 1983, 2001), are numerically depicted in Table 1 and summarized as follows, according to Coelho $(2011,2015$, 2017) and to Barata and Coelho (2015):

1. Power Distance Index (pdi) - Power distance is the extent to which less powerful members of organizations expect power to be equally distributed (Hofstede, 1980). In low power distance countries there is limited dependence of subordinates on their bosses. Power is very decentralized as well as decision-making. In contrast, in high power distance countries, hierarchy is the fundamental principle on which all relationships are based. Power is centralized as well as decision-making, leading to more emphasis on formal methods for gathering and analyzing external information (Flynn \& Sala-din, 2006).

2. Individualism versus Collectivism (idv) - Individualism is the degree to which people are oriented towards acting as individuals as opposed to acting as a group (Hofstede, 1980). In individualist countries people tend to value individual success and achievement. Members of individualist countries are autonomous and confident, tending to rely primarily on their own ideas (Snell \& Hui, 2000). In collectivist countries, people are bound in groups such as the extended family or the village and are more likely to rely on information provided by others in formulating their opinions (Snell \& Hui, 2000).

3. Masculinity versus Femininity (mas) - Masculinity is the extent to which success and aggressiveness are valued (Hofstede, 1980). In high masculinity countries, high earnings, advancement through opportunities and challenging work are mostly emphasized. The use of information to support decision-making is dependent on its expected effectiveness in gaining advantage over competitors (Flynn \& Saladin, 2006). In contrast, in high femininity countries, relationships, concern for the others, in-clusiveness and society's best interest are valued. Cooperation is often a visible feature. The use of information to support decision-making is very typical of a feminine national culture (Wacker \& Sprague, 1998).

4. Uncertainty Avoidance Index (uai) - Uncertainty avoidance is the degree to which people feel confident about the future (Hofstede, 2001). National cultures that score high in uncertainty avoidance have an emotional need for rules. Vice versa, national cultures that score low in uncertainty avoidance dislike formal rules, setting them only when it is necessary (Flynn \& Saladin, 2006).

5. Long Term Orientation versus Short Term Normative Orientation (Itowvs) - Long term orientation stands for the fostering of virtues oriented towards future rewards, in particular perseverance and thrift. It's opposite pole, short term orientation, stands for the fostering of virtues related to the past and present, in particular, respect for tradition, preservation of 'face' and fulfilling social obliga-tions.

6. Indulgence versus Restraint (ivr) - Indulgence stands for a society that allows relatively free gratification of basic and natural human drives related to enjoying life and having fun. Restraint stands for a society that suppresses gratification of needs and regulates it by means of strict social norms.

Geert Hofstede conducted one of the most comprehensive studies of how values in the workplace are influenced by culture. He analyzed a large database of employee value scores collected within IBM between 1967 and 1973. The data covered more than 70 countries, from which Hofstede first used the 40 countries with the largest groups of respondents and afterwards extended the analysis to 50 countries and 3 regions. Subsequent studies validating the earlier results include such respondent groups as commercial airline pilots and students in 23 countries, civil service managers in 14 counties, 'up-market' consumers in 15 countries and 'elites' in 19 countries. In the 2010 edition of the book Cul-tures and Organizations: Software of the Mind, scores on the dimensions are listed for 76 countries, partly 
based on replications and extensions of the IBM study on different international populations and by different scholars.

In what concerns the current validity of Hofstede's cultural measures, criticisms addressed to the construct of national culture as a suitable variable for differentiation, apply directly to all measures (Coelho, 2011). Different corporate, organizational, industrial and/or sector specific cultures may co-exist within the same firm and might as well conflict and counterbalance the national one (Vecchi \& Brennan, 2009).

Furthermore, in many countries, different ethnic or national cultures co-exist $(A u, 2000)$, as result of people mobility around the globe. Within the same country, different sub-cultures might persist, standing apart on religious, language or ethnicity grounds. As a consequence, the four me- asures of national cultures could be far from being reliable proxies for cultural homogeneity for a given national culture $(A u, 2000)$.

The data extracted from Hofstede's measures of national culture, that was used in the correlation analyses is presented in Table 5. The data has been cross-validated in an empirical study by van Oudenhoven (2001) for Belgium, Denmark, Germany, United Kingdom, Greece, Spain and the Netherlands. The country scores on the dimensions are relative - societies are compared to other societies. It is thought that these relative scores have been proven to be quite stable over decades. The forces that cause cultures to shift tend to be global or continent-wide - they affect many countries at the same time, so that if their cultures shift, they shift together, and their relative positions tend to remain the same. 
Table 5. Hofstede's national dimensions of culture (Hofstede Centre, 2015) for 31 European countries (source: http://www.geerthofstede.com/research—vsm, accessed February 2015), (legend of headings given in main text in the current section)

Tablica 5. Nacionalna kulturna obilježja prema Hofstede-u (Hofstede Centre, 2015.) za 31 europsku zemlju (izvor: http://geerthofstede.com/research--vsm, konzultirano u veljači 2015.), (legenda naslova nalazi se u glavnom tekstu ovog dijela)

\begin{tabular}{|c|c|c|c|c|c|c|}
\hline Country & pdi & idv & mas & uai & Itowvs & ivr \\
\hline Austria & 11 & 55 & 79 & 70 & 60 & 63 \\
\hline Belgium & 65 & 75 & 54 & 94 & 82 & 57 \\
\hline Bulgaria & 70 & 30 & 40 & 85 & 69 & 16 \\
\hline Croatia & 73 & 33 & 40 & 80 & 58 & 33 \\
\hline Czech Rep & 57 & 58 & 57 & 74 & 70 & 29 \\
\hline Denmark & 18 & 74 & 16 & 23 & 35 & 70 \\
\hline Estonia & 40 & 60 & 30 & 60 & 82 & 16 \\
\hline Finland & 33 & 63 & 26 & 59 & 38 & 57 \\
\hline France & 68 & 71 & 43 & 86 & 63 & 48 \\
\hline Germany & 35 & 67 & 66 & 65 & 83 & 40 \\
\hline Great Britain & 35 & 89 & 66 & 35 & 51 & 69 \\
\hline Greece & 60 & 35 & 57 & 112 & 45 & 50 \\
\hline Hungary & 46 & 80 & 88 & 82 & 58 & 31 \\
\hline Ireland & 28 & 70 & 68 & 35 & 24 & 65 \\
\hline Italy & 50 & 76 & 70 & 75 & 61 & 30 \\
\hline Latvia & 44 & 70 & 9 & 63 & 69 & 13 \\
\hline Lithuania & 42 & 60 & 19 & 65 & 82 & 16 \\
\hline Luxembourg & 40 & 60 & 50 & 70 & 64 & 56 \\
\hline Malta & 56 & 59 & 47 & 96 & 47 & 66 \\
\hline Netherlands & 38 & 80 & 14 & 53 & 67 & 68 \\
\hline Norway & 31 & 69 & 8 & 50 & 35 & 55 \\
\hline Poland & 68 & 60 & 64 & 93 & 38 & 29 \\
\hline Portugal & 63 & 27 & 31 & 104 & 28 & 33 \\
\hline Romania & 90 & 30 & 42 & 90 & 52 & 20 \\
\hline Serbia & 86 & 25 & 43 & 92 & 52 & 28 \\
\hline Slovak Rep & 104 & 52 & 110 & 51 & 77 & 28 \\
\hline Slovenia & 71 & 27 & 19 & 88 & 49 & 48 \\
\hline Spain & 57 & 51 & 42 & 86 & 48 & 44 \\
\hline Sweden & 31 & 71 & 5 & 29 & 53 & 78 \\
\hline Switzerland & 34 & 68 & 70 & 58 & 74 & 66 \\
\hline Turkey & 66 & 37 & 45 & 85 & 46 & 49 \\
\hline
\end{tabular}




\section{SELECTION OF DIMENSIONS FROM THE EUROPEAN WORKING CONDITIONS SURVEY (2015 DATA)}

Since its launch in 1990, the European Working Conditions Survey (EWCS) has provided an overview of working conditions in Europe (EUROFOUND, 2017). Themes covered today include employment status, working time duration and organization, work organization, learning and training, physical and psychosocial risk factors, health and safety, work-life balance, worker participation, earnings and financial security, as well as work and health. For the purpose of the analysis reported on this paper, a selection was made of indicators extracted from the $6^{\text {th }}$ EWCS 2015 data. Tables 6 and 7 depict the result of the selection regarding physical and psychosocial exposures. The selection was subjectively carried out by the researcher, based on the perception of the most impactful themes covered in the 6th EWCS 2015 data. Selected average scores per country were obtained from the dataset (Tables 8 and 9). In this process, the response scale items were considered in a question by question approach (answer ranges shown to survey respondents are given in the Tables captions).

Table 6. Physical variables of the EWCS (2015) selected for analysis

Tablica 6. Fizičke varijable EWCS-a (2015.) odabrane za analizu

\begin{tabular}{|c|l||}
\hline Variable & \multicolumn{1}{|c|}{ [are you exposed at work to...? does your main job involve...?] } \\
\hline Q29a & Vibrations from hand tools, machinery etc. \\
\hline Q29b & Noise so loud that you would have to raise your voice to talk to people \\
\hline Q29c & High temperatures which make you perspire even when not working \\
\hline Q29d & Low temperatures whether indoors or outdoors \\
\hline Q29e & Breathing in smoke, fumes (such as welding or exhaust fumes), powder or dust (such as wood dust or mineral dust) etc. \\
\hline Q29g & Handling or being in skin contact with chemical products or substances \\
\hline Q29i & $\begin{array}{l}\text { Handling or being in direct contact with materials which can be infectious, such as waste, bodily fluids, laboratory } \\
\text { materials, etc. }\end{array}$ \\
\hline Q30a & Tiring or painful positions \\
\hline Q30b & Lifting or moving people \\
\hline Q30c & Carrying or moving heavy loads \\
\hline Q30e & Repetitive hand or arm movements \\
\hline Q30g & Handling angry clients, customers, patients, pupils etc. \\
\hline Q30h & Being in situations that are emotionally disturbing for you \\
\hline Q30i & Working with computers, laptops, smartphones etc. \\
\hline \hline
\end{tabular}

Table 7. Psychosocial variables of the EWCS (2015) selected for analysis

Tablica 7. Psihosocijalne varijable EWCS-a (2015.) odabrane za analizu

\begin{tabular}{|c|l||}
\hline Variable & \multicolumn{1}{|c|}{ [to what extent do you agree with the following statements about your job...?] } \\
\hline Q89c & I receive the recognition I deserve for my work \\
\hline Q89d & I generally get on well with my work colleagues \\
\hline Q89e & The organization I work for motivates me to give my best job performance \\
\hline Q89f & I get on better with my children because I have a job \\
\hline Q89g & I might lose my job in the next 6 months \\
\hline Q89h & If I were to lose or quit my current job, it would be easy for me to find a job of similar salary \\
\hline
\end{tabular}


Table 8. Part 1 of 2 of selected average scores per country obtained from the dataset (EWCS, 2015) (legend of headings given in Table 6) (scale: 1 - All of the time -- 7 - Never)

Tablica 8. Prvi od dva dijela odabranih prosječnih rezultata po zemljama iz podataka (EWCS, 2015.); (legenda naslova nalazi se u Tablici 6); (skala: 1-Stalno do 7-Nikad)

\begin{tabular}{|c|c|c|c|c|c|c|c|c|c|c|}
\hline Country & Q29a & Q29b & Q29c & Q29d & Q29e & Q29g & Q29i & Q30a & Q30b & Q30c \\
\hline Austria & 6.17 & 5.92 & 6.01 & 6.40 & 6.42 & 6.34 & 6.45 & 5.24 & 6.61 & 5.75 \\
\hline Belgium & 6.43 & 6.07 & 6.31 & 6.38 & 6.46 & 6.43 & 6.43 & 5.37 & 6.51 & 5.85 \\
\hline Czech Republic & 6.27 & 5.96 & 6.23 & 6.35 & 6.40 & 6.45 & 6.61 & 5.86 & 6.69 & 5.84 \\
\hline Denmark & 6.35 & 5.80 & 5.99 & 6.12 & 6.59 & 6.50 & 6.29 & 5.85 & 6.60 & 5.96 \\
\hline Estonia & 5.96 & 5.80 & 6.37 & 6.14 & 6.31 & 6.30 & 6.58 & 5.32 & 6.67 & 5.71 \\
\hline Finland & 6.05 & 5.62 & 6.10 & 6.08 & 6.13 & 6.18 & 6.33 & 5.53 & 6.57 & 5.61 \\
\hline France & 6.11 & 5.76 & 6.15 & 6.23 & 6.29 & 6.24 & 6.41 & 5.16 & 6.54 & 5.68 \\
\hline Germany & 6.07 & 5.92 & 6.18 & 6.40 & 6.45 & 6.31 & 6.53 & 5.42 & 6.67 & 5.88 \\
\hline Hungary & 5.95 & 6.00 & 6.14 & 6.12 & 6.23 & 6.14 & 6.40 & 5.27 & 6.51 & 5.85 \\
\hline Ireland & 6.36 & 6.05 & 6.30 & 6.18 & 6.59 & 6.27 & 6.28 & 5.78 & 6.44 & 5.76 \\
\hline Lithuania & 5.98 & 5.81 & 6.18 & 6.13 & 6.24 & 6.28 & 6.31 & 5.06 & 6.69 & 5.63 \\
\hline Netherlands & 6.42 & 6.15 & 6.08 & 6.30 & 6.50 & 6.58 & 6.45 & 5.74 & 6.57 & 5.97 \\
\hline Norway & 6.14 & 5.88 & 6.25 & 5.99 & 6.54 & 6.40 & 6.25 & 5.97 & 6.35 & 5.67 \\
\hline Poland & 5.93 & 5.69 & 5.94 & 6.12 & 6.22 & 6.14 & 6.49 & 5.17 & 6.64 & 5.72 \\
\hline Portugal & 6.08 & 6.26 & 6.35 & 6.47 & 6.55 & 6.57 & 6.68 & 5.01 & 6.56 & 6.03 \\
\hline Slovenia & 6.10 & 5.63 & 5.91 & 6.22 & 6.33 & 6.38 & 6.53 & 4.96 & 6.67 & 5.88 \\
\hline Spain & 6.06 & 5.84 & 5.42 & 5.92 & 6.37 & 6.07 & 6.36 & 4.66 & 6.52 & 5.37 \\
\hline Sweden & 6.32 & 5.73 & 6.11 & 6.20 & 6.44 & 6.36 & 6.33 & 5.34 & 6.38 & 5.60 \\
\hline Switzerland & 6.18 & 6.06 & 6.10 & 6.30 & 6.43 & 6.37 & 6.48 & 5.24 & 6.68 & 5.91 \\
\hline United Kingdom & 6.47 & 6.01 & 6.16 & 6.11 & 6.45 & 6.16 & 6.24 & 5.74 & 6.49 & 5.68 \\
\hline
\end{tabular}


Table 9. Part 2 of 2 of selected average scores per country obtained from the dataset (EWCS, 2015) (legend of headings given in Tables 7 and 8) (scale for Q30: 1 - All of the time -- 7 - Never; scale for Q89: 1-Strongly Agree -- 5-Strongly disagree)

Tablica 9. Drugi od dva dijela odabranih prosječnih rezultata po zemljama iz podataka (EWCS, 2015.) (legenda naslova nalazi se u tablicama 7 i 8); (skala za Q30: 1-Stalno do 7-Nikad; skala za Q 89: 1-Potpuno se slažem do 5-Uopće se ne slažem)

\begin{tabular}{|c|c|c|c|c|c|c|c|c|c|c|}
\hline Country & Q30e & Q30g & Q30h & Q30i & Q89c & Q89d & Q89e & Q89f & Q89g & Q89h \\
\hline Austria & 4.68 & 5.69 & 5.54 & 4.29 & 2.13 & 1.57 & 2.24 & 2.72 & 4.13 & 3.24 \\
\hline Belgium & 4.53 & 5.56 & 5.88 & 4.04 & 2.23 & 1.54 & 2.22 & 2.68 & 4.09 & 3.18 \\
\hline Czech Republic & 4.48 & 5.89 & 5.83 & 4.98 & 2.30 & 1.74 & 2.39 & 2.56 & 3.62 & 3.37 \\
\hline Denmark & 4.52 & 5.86 & 5.85 & 3.22 & 1.99 & 1.21 & 2.07 & 2.27 & 4.44 & 2.75 \\
\hline Estonia & 3.94 & 5.87 & 5.78 & 4.27 & 2.31 & 1.53 & 2.32 & 2.47 & 3.67 & 3.09 \\
\hline Finland & 3.86 & 6.02 & 5.62 & 4.36 & 2.04 & 1.29 & 2.01 & 2.12 & 4.15 & 3.15 \\
\hline France & 4.34 & 5.44 & 5.72 & 4.51 & 2.33 & 1.60 & 2.44 & 2.84 & 4.18 & 3.20 \\
\hline Germany & 4.91 & 5.74 & 5.83 & 4.93 & 2.35 & 1.58 & 2.40 & 2.90 & 4.19 & 3.17 \\
\hline Hungary & 4.68 & 5.87 & 5.92 & 5.06 & 2.42 & 1.82 & 2.36 & 2.30 & 3.79 & 3.37 \\
\hline Ireland & 4.74 & 5.50 & 6.17 & 4.20 & 2.20 & 1.39 & 2.19 & 2.11 & 4.07 & 3.23 \\
\hline Lithuania & 4.21 & 5.66 & 5.21 & 5.14 & 2.50 & 1.71 & 2.75 & 2.38 & 3.68 & 3.11 \\
\hline Netherlands & 4.33 & 5.85 & 6.06 & 3.74 & 2.02 & 1.26 & 2.12 & 2.52 & 3.89 & 3.35 \\
\hline Norway & 4.73 & 5.86 & 5.93 & 3.54 & 1.88 & 1.20 & 1.92 & 2.16 & 4.44 & 2.72 \\
\hline Poland & 4.42 & 5.47 & 5.51 & 5.11 & 2.54 & 1.88 & 2.52 & 2.48 & 3.46 & 3.11 \\
\hline Portugal & 3.86 & 5.20 & 6.18 & 5.24 & 2.27 & 1.49 & 2.24 & 2.73 & 3.57 & 3.88 \\
\hline Slovenia & 3.84 & 5.51 & 5.44 & 4.26 & 2.78 & 1.42 & 2.37 & 2.11 & 3.65 & 3.52 \\
\hline Spain & 3.64 & 4.81 & 5.49 & 4.68 & 2.30 & 1.49 & 2.31 & 3.05 & 3.60 & 3.47 \\
\hline Sweden & 4.19 & 5.56 & 5.78 & 3.59 & 2.27 & 1.46 & 2.34 & 2.45 & 4.21 & 2.69 \\
\hline Switzerland & 4.58 & 5.37 & 5.66 & 4.52 & 2.08 & 1.61 & 1.99 & 2.71 & 4.14 & 3.01 \\
\hline United Kingdom & 4.31 & 5.50 & 5.99 & 3.79 & 2.29 & 1.48 & 2.28 & 2.34 & 4.04 & 2.86 \\
\hline
\end{tabular}




\section{RESULTS OF ANALYSIS OF ASSOCIATION}

Association between the fatal and non-fatal accidents at work statistics (in per capita formulation) presented in section 2, and the selected social dimensions presented in section 3 was made based on data from 20 countries that were matched across the two datasets. Table 10 depicts the pairs of variables where Pearson correlation factors above 0.45 were found. Both dimensions of accidents at work statistics are equally salient in this analysis. The social dimensions that are more salient in this analysis are those of satisfaction with life as a whole, frequency of social meetings and importance given to equally of treatment and opportunities as well as of following rules.

Table 10. Strong Pearson correlations (above 0.45 in absolute value) resulting from associating the fatal and non-fatal accidents at work statistics (in per capita formulation) with selected dimensions of the ESS7 (2014); variable names explained in section 2 and Table 2; p-values shown in parentheses; $\mathbf{n}=\mathbf{2 0}$

Tablica 10. Visoke Pearsonove korelacije (iznad 0.45 u apsolutnoj vrijednosti) rezultiraju iz statistike povezanosti smrtnih $i$ nesmrtnih nesreća na radu (izraženo per capita) i određenih obilježja iz ESS7 (2014.); nazivi varijabli objašnjeni u dijelu 2 i Tablici 2; pvrijednosti navedene $u$ zagradama; $n=20$

\begin{tabular}{|c|c|c|c|c||}
\hline $\begin{array}{c}\text { Accidents at } \\
\text { work / ESS7 }\end{array}$ & stflife & sclmeet & ipeqopt & ipfrule \\
\hline $\begin{array}{c}\text { Fatal accidents } \\
\text { at work }\end{array}$ & $\begin{array}{c}-0.555 \\
(0.011)\end{array}$ & - & $\begin{array}{c}0.457 \\
(0.043)\end{array}$ & - \\
\hline $\begin{array}{c}\text { Non-fatal } \\
\text { accidents at work }\end{array}$ & - & $\begin{array}{c}0.581 \\
(0.007)\end{array}$ & - & $\begin{array}{c}0.451 \\
(0.046)\end{array}$ \\
\hline
\end{tabular}

Association between the national dimensions of culture presented in section 4, and the selected social dimensions presented in section 3 was made based on data from 20 countries that were matched across the two datasets. Table 11 depicts the pairs of variables where Pearson correlation factors above 0.5 were found. The dimensions of culture that are more salient in this analysis are power distance, uncertainty avoidance and indulgence versus restraint. The social dimensions that are more salient in this analysis are those of trust in other people and trust in the legal system.
Table 11. Strong Pearson correlations (above 0.5 in absolute value) resulting from associating the National Dimensions of Culture (NDC) with selected dimensions of the ESS7 (European Social Survey - round 7, 2014 data); ESS7 variable names explained in section 3 and Table 2; NDC abbreviations explained in section 4 ; $p$-values shown in parentheses; $\mathbf{n}=\mathbf{2 0}$

Tablica 11. Visoke Pearsonove korelacije (iznad 0.5 u apsolutnoj vrijednosti) rezultiraju iz povezanosti Nacionalnih kulturnih obilježja (NDC) i odabranih obilježja iz ESS7 (2014.); ESS7 varijable objašnjene u dijelu 3 i Tablici 2; NDC kratice objašnjene u dijelu 4; p-vrijednosti navedene u zagradama; $\mathbf{n}=\mathbf{2 0}$

\begin{tabular}{|c|c|c|c|c|c|}
\hline $\begin{array}{l}\text { ESS7/ } \\
\text { NDC }\end{array}$ & pdi & idv & uai & Itowvs & ivr \\
\hline ppltrst & $\begin{array}{l}-0.696 \\
(0.001)\end{array}$ & $\begin{array}{c}0.505 \\
(0.023)\end{array}$ & $\begin{array}{c}-0.786 \\
(<0.001)\end{array}$ & - & $\begin{array}{c}0.589 \\
(0.006)\end{array}$ \\
\hline pplhlp & $\begin{array}{c}-0.732 \\
(<0.001)\end{array}$ & - & $\begin{array}{c}-0.879 \\
(<0.001)\end{array}$ & - & $\begin{array}{c}0.756 \\
(<0.001)\end{array}$ \\
\hline trstlgl & $\begin{array}{c}-0.769 \\
(<0.001)\end{array}$ & $\begin{array}{c}0.594 \\
(0.006)\end{array}$ & $\begin{array}{c}-0.757 \\
(<0.001)\end{array}$ & - & $\begin{array}{c}0.619 \\
(0.004) \\
\end{array}$ \\
\hline stflife & $\begin{array}{l}-0.553 \\
(0.011) \\
\end{array}$ & - & $\begin{array}{l}-0.593 \\
(0.006)\end{array}$ & - & $\begin{array}{c}0.771 \\
(<0.001)\end{array}$ \\
\hline health & $\begin{array}{c}0.544 \\
(0.013)\end{array}$ & - & $\begin{array}{c}0.602 \\
(0.005)\end{array}$ & - & $\begin{array}{c}-0.795 \\
(<0.001)\end{array}$ \\
\hline gndr & - & - & - & - & $\begin{array}{l}-0.593 \\
(0.006) \\
\end{array}$ \\
\hline edulvlb & - & $\begin{array}{c}0.559 \\
(0.010) \\
\end{array}$ & $\begin{array}{l}-0.597 \\
(0.005)\end{array}$ & - & - \\
\hline wrkctra & - & - & - & $\begin{array}{l}-0.580 \\
(0.007) \\
\end{array}$ & - \\
\hline ipadvnt & - & - & $\begin{array}{c}0.579 \\
(0.007)\end{array}$ & - & $\begin{array}{l}-0.524 \\
(0.018)\end{array}$ \\
\hline
\end{tabular}

Association between the national dimensions of culture presented in section 4, and the selected working conditions dimensions presented in section 5 was made based on data from 20 countries that were matched across the two datasets. Table 12 depicts the pairs of variables where Pearson correlation factors above 0.5 were found. The dimensions of culture that are more salient in this analysis are indulgence versus restraint and uncertainty avoidance. The physical working dimensions that are more salient in this analysis of association are those of 'Handling or being in direct contact with materials which can be infectious, such as waste, bodily fluids, laboratory ma- 
terials, etc.' as well as 'Tiring or painful positions'. The psychosocial working dimensions that display a great number of associations with the cultural dimensions are those concerned with job insecurity, recognition for work, ease of working with colleagues and prospects of finding a new job if needed.

Table 12. Strong Pearson correlations (above 0.5 in absolute value) resulting from associating the National Dimensions of Culture (NDC) with selected dimensions of the $6^{\text {th }}$ EWCS (European Working Conditions Survey, 2015 da-ta); EWCS variable names explained in section 5 and Tables 6 and 7; NDC abbreviations explained in section 4; p-values shown in parentheses; $\mathbf{n}=\mathbf{2 0}$

Tablica 12. Visoke Pearsonove korelacije (iznad 0.5 u apsolutnoj vrijednosti) rezultat su povezanosti Nacionalnih kulturnih obilježja (NDC) i odabranih obilježja iz 6. EWCSs (European Working Conditions Survey, 2015.); EWC varijable objašnjene u dijelu 5 i tablicama 6 i 7; NDC kratice objašnjene u dijelu 4; p-vrijednosti navedene u zagradama; $\mathbf{n}=\mathbf{2 0}$

\begin{tabular}{|c|c|c|c|c|c|}
\hline $\begin{array}{c}\text { EWCS/ } \\
\text { NDC }\end{array}$ & pdi & idv & mas & uai & ivr \\
\hline Q29a & - & - & - & $\begin{array}{l}-0.522 \\
(0.018)\end{array}$ & $\begin{array}{c}0.753 \\
(<0.001)\end{array}$ \\
\hline Q29e & - & - & - & - & $\begin{array}{c}0.507 \\
(0.022)\end{array}$ \\
\hline Q29i & - & $\begin{array}{l}-0.597 \\
(0.005)\end{array}$ & - & $\begin{array}{c}0.630 \\
(0.003) \\
\end{array}$ & $\begin{array}{l}-0.503 \\
(0.024)\end{array}$ \\
\hline Q30a & $\begin{array}{l}-0.503 \\
(0.024)\end{array}$ & $\begin{array}{c}0.578 \\
(0.008)\end{array}$ & - & $\begin{array}{l}-0.660 \\
(0.002)\end{array}$ & - \\
\hline Q30b & - & - & - & - & $\begin{array}{l}-0.513 \\
(0.021)\end{array}$ \\
\hline Q30e & - & $\begin{array}{c}0.551 \\
(0.012)\end{array}$ & - & - & - \\
\hline Q30i & - & - & - & $\begin{array}{c}0.712 \\
(<0.001)\end{array}$ & $\begin{array}{c}-0.765 \\
(<0.001)\end{array}$ \\
\hline Q89C & $\begin{array}{c}0.639 \\
(0.002)\end{array}$ & - & - & $\begin{array}{c}0.506 \\
(0.023)\end{array}$ & $\begin{array}{l}-0.543 \\
(0.013)\end{array}$ \\
\hline Q89d & - & - & $\begin{array}{c}0.619 \\
(0.004)\end{array}$ & $\begin{array}{c}0.529 \\
(0.016)\end{array}$ & $\begin{array}{l}-0.612 \\
(0.004) \\
\end{array}$ \\
\hline Q89e & - & - & - & - & $\begin{array}{l}-0.631 \\
(0.003) \\
\end{array}$ \\
\hline Q89g & $\begin{array}{l}-0.638 \\
(0.002) \\
\end{array}$ & $\begin{array}{c}0.535 \\
(0.015)\end{array}$ & - & $\begin{array}{l}-0.629 \\
(0.003)\end{array}$ & $\begin{array}{c}0.711 \\
(<0.001)\end{array}$ \\
\hline Q89h & $\begin{array}{c}0.553 \\
(0.011)\end{array}$ & $\begin{array}{l}-0.651 \\
(0.002)\end{array}$ & - & $\begin{array}{c}0.748 \\
(<0.001)\end{array}$ & - \\
\hline
\end{tabular}

Association between the fatal and non-fatal accidents at work statistics (in per capita formulation) presented in section 2, and the selected working conditions dimensions presented in section 5 was made based on data from 20 countries that were matched across the two datasets. Table 13 depicts the pairs of variables where Pearson correlation factors above 0.45 were found. Both per capita dimensions of accidents at work statistics are equally salient in this analysis. The physical working dimensions that is most salient in this analysis of association concerns vibrations from hand tools and machinery. The psychosocial working dimensions that display a great number of associations with the accidents at work statistics are those concerned with the average per country score of responses given to 'getting on better with own children because of having a job'. A third set of associations concerns the correlation between selected social and working conditions dimensions (Table 14). Most salient social dimensions in the analysis are peoples' perceived helpfulness, subjective general health, peoples' perceived trustworthiness, the trustworthiness of the legal system and the level of satisfaction with life as a whole. In what concerns physical working conditions, the variables most involved in the strong correlations are experiencing tiring or painful positions and working with electronic devices. Salient psychosocial factors are recognition for work, organization motivated performance, job insecurity and prospects of finding a new job if needed.

Table 13. Strong Pearson correlations (above 0.5 inabsolute value) resulting from associating the fatal and non-fatal accidents at work statistics (in per capita formulation) with selected dimensions of the $6^{\text {th }}$ EWCS [2] (inverted answer coding); variable names explained in section 2 and Tables 5 and 6; $\mathrm{p}$-values shown in parentheses; $\mathbf{n}=\mathbf{2 0}$

Tablica 13. Visoke Pearsonove korelacije (iznad 0.5 u apsolutnoj vrijednosti rezultat su statistike povezanosti smrtnih i nesmrtnih nesreća na radu (per capita) i odabranih obilježja iz 6. EWCS (2) (obrnutog kodiranja odgovora); nazivi varijabli objašnjeni u dijelu 2 i tablicama 5 i 6; p-vrijednosti nalaze se u zagradama; $\mathrm{n}=\mathbf{2 0}$

\begin{tabular}{||c|c|c||}
\hline $\begin{array}{c}\text { Accidents at work } \\
/ \mathbf{6}^{\text {th }} \text { EWCS }\end{array}$ & Q29a & Q89f \\
\hline $\begin{array}{c}\text { Fatal accidents } \\
\text { at work }\end{array}$ & $-0.482(0.031)$ & - \\
\hline $\begin{array}{c}\text { Non-fatal accidents } \\
\text { at work }\end{array}$ & - & $0.534(0.015)$ \\
\hline
\end{tabular}


Table 14. Strong Pearson correlations (above 0.5 in absolute value) resulting from associating the selected the ESS7 [1] with selected dimensions of the $6^{\text {th }}$ EWCS [2] (inverted answer coding); variable names explained in Tables 2, 5 and 6; ${ }^{* *}$. correlation is significant at the 0.01 level (2-tailed); ${ }^{*}$ correlation is significant at the 0.05 level (2-tailed); $n=20$

Tablica 14. Visoke Pearsonove korelacije (iznad 0.5 u apsolutnoj vrijednosti rezultat su povezanosti odabranih ESS7 (1) obilježja i odabranih obilježja iz 6. EWCS (2) (obrnutog kodiranja odgovora; nazivi varijabli su u tablicama 2, 5 i 6; ** korelacija je značajna na razini od 0.01 (2-kraka); *korelacija je značajna na razini 0.05 (dva kraka); $n=20$

\begin{tabular}{|c|c|c|c|c|c|c|c|c|c|c|c|c|}
\hline $\begin{array}{l}\text { ESS7/ } \\
6 E W C S\end{array}$ & ppltrst & pplhlp & trstlgl & stflife & $\begin{array}{c}\text { scl- } \\
\text { meet }\end{array}$ & health & gndr & $\begin{array}{l}\text { edu- } \\
\text { Ivlb }\end{array}$ & $\begin{array}{c}\text { ip- } \\
\text { eqopt }\end{array}$ & ipshabt & $\begin{array}{l}\text { ip- } \\
\text { advnt }\end{array}$ & $\begin{array}{l}\text { imp- } \\
\text { trad }\end{array}$ \\
\hline Q29a & - & $.561^{*}$ & - & $.504 *$ & - & $-.676^{* *}$ & - & - & - & - & $-.527^{*}$ & - \\
\hline Q29C & - & - & - & - & - & - & - & - & $.638^{* *}$ & - & - & - \\
\hline Q29e & - & - & - & - & $.572^{* *}$ & $-.512^{*}$ & - & - & - & - & - & - \\
\hline Q29g & - & - & - & - & $.505^{*}$ & - & - & - & - & - & - & - \\
\hline Q29i & $-.567^{* *}$ & $-.573^{* *}$ & - & - & - & - & - & - & - & - & - & - \\
\hline Q30a & $.586^{* *}$ & $.643^{* *}$ & $.661^{* *}$ & - & - & $-.583^{* *}$ & - & $.546^{*}$ & - & - & $-.551 *$ & - \\
\hline Q30e & - & - & - & - & - & $-.506^{*}$ & - & - & - & - & - & - \\
\hline Q30g & - & - & - & - & - & - & - & $.670^{* *}$ & $.520^{*}$ & - & - & - \\
\hline Q30i & $-.779 * *$ & $-.806^{* *}$ & $-.686^{* *}$ & $-.717^{* *}$ & - & $.633^{* *}$ & - & $-.522^{*}$ & - & - & $.618^{* *}$ & - \\
\hline Q89c & $-.761^{* *}$ & $-.623^{* *}$ & $-.841^{* *}$ & $-.672 * *$ & $-.579 * *$ & $.619^{* *}$ & $.509 *$ & - & - & $-.525^{*}$ & - & - \\
\hline Q89d & $-.716^{* *}$ & $-.737^{* *}$ & $-.583^{* *}$ & $-.580 * *$ & $-.664^{* *}$ & - & - & - & - & - & - & - \\
\hline Q89e & $-.645^{* *}$ & $-.646^{* *}$ & $-.683^{* *}$ & $-.694^{* *}$ & $-.568^{* *}$ & $.589^{* *}$ & $.598^{* *}$ & - & - & - & - & - \\
\hline Q89f & - & - & - & - & - & - & - & - & - & - & $.626^{* *}$ & - \\
\hline Q89g & $.753^{* *}$ & $.796^{* *}$ & $.879 * *$ & $.731^{* *}$ & - & $-.701^{* *}$ & $-.627^{* *}$ & $.605^{* *}$ & - & - & - & $.564^{* *}$ \\
\hline Q89h & $-.735^{* *}$ & $-.663^{* *}$ & $-.729 * *$ & $-.642^{* *}$ & - & $.571 * *$ & - & $-.785^{* *}$ & - & - & - & - \\
\hline
\end{tabular}

Linear regression modelling (forward method) of fatal work accidents per capita was pursued, taking as independent variables all other variables present in this study. This modelling effort resulted in a determination coefficient of 0.308 , with a single standardized coefficient of satisfaction with life as a whole at -0.555 , with a significance level of 0.011 . Adding the national dimensions of culture to the independent variable pool in the regression of fatal accidents at work, yields a determination coefficient of 0.631 , for the cultural dimension of individuality at -0.653 standardized coefficient $(p<0.001)$ and the importance of equal treatment and opportunities at 0.521 standardized coefficient $(p=0.003)$. Linear regression modelling (forward method) of non-fatal work accidents per 
capita ensued, taking as independent variables all remaining variables included in the study, except for fatal accidents at work. This modelling effort led to a very high determination coefficient of 0.901, based on a six independent variables model (Table 15). The regression model includes four social variables (education level, gender imbalance, importance given to rules and frequency of socializing) and two occupational exposures (lifting or moving people and handling angry clients). When national dimensions of culture are added to the pool of independent variables for linear regression, the determination coefficient increases slightly to 0.937 with four social variables (gender imbalance, importance given to rules and frequency of socializing), tow occupational exposures (lifting or moving people and being in emotionally disturbing situations) and one cultural dimension (long term orientation versus short term orientation). The standardized coefficients for these variables and the significance levels are shown in Table 16.

Table 15. Standardized coefficients for the linear regression of the dependent variable 'nonfatal accidents per capita' on social and occupational exposure independent variables (coding of varia-bles presented in Tables 2 and 6); $\mathbf{n = 2 0}$

Tablica 15. Standardizirani koeficijenti za linearnu regresiju zavisne varijable 'nesmrtne nesreće per capita' na nezavisne varijable društvene i radne izloženosti (kodiranje varijabli prikazano u tablicama 2 i 6); $\mathbf{n}=\mathbf{2 0}$

\begin{tabular}{|c|c|c|}
\hline $\begin{array}{c}\text { Independent } \\
\text { variable }\end{array}$ & $\begin{array}{c}\text { Standardized } \\
\text { coefficient }\end{array}$ & Significance \\
\hline sclmeet & 0.402 & 0.007 \\
\hline Q30b & 0.584 & $<0.001$ \\
\hline Ipfrule & 0.609 & $<0.001$ \\
\hline Gndr & -0.605 & 0.001 \\
\hline Edulvlb & -0.522 & 0.002 \\
\hline Q30g & 0.359 & 0.026 \\
\hline
\end{tabular}

Table 16. Standardized coefficients for the linearregression of the dependent variable 'non-fatal accidents per capita' on national dimensions of culture and social and occupational exposure independent variables (coding of variables presented in Tables 2, 5 and 6); $n=20$

Tablica 16. Standardizirani koeficijenti za linearnu regresiju zavisne varijable 'nesmrtne nesreće per capita' na nezavisne varijable nacionalnih kulturnih obilježja $i$ radne izloženosti (kodiranje varijabli u tablicama 2, 5 i 6); $\mathbf{n = 2 0}$

\begin{tabular}{|c|c|c||}
\hline $\begin{array}{c}\text { Independent } \\
\text { variable }\end{array}$ & $\begin{array}{c}\text { Standardized } \\
\text { coefficient }\end{array}$ & Significance \\
\hline sclmeet & 0.331 & 0.007 \\
\hline Q30b & 0.867 & $<0.001$ \\
\hline Ipfrule & 0.675 & $<0.001$ \\
\hline $\begin{array}{c}\text { Long term } \\
\text { versus short term } \\
\text { orientation }\end{array}$ & -0.447 & $<0.001$ \\
\hline gndr & -0.483 & $<0.001$ \\
\hline Q30h & 0.187 & 0.042 \\
\hline
\end{tabular}

\section{DISCUSSION}

The results of association suggest that countries where people report a lower average degree of satisfaction with life as a whole (e.g. Portugal, Lithuania, Hungary) are bound to incur higher number of per capita fatal accidents at work. The moderate correlation found between the latter and the average score given by people to the importance of equal treatment and equal opportunities, suggests that countries where people on average give more relative importance to this issue (e.g. Spain, Slovenia) show a moderate tendency to display higher numbers of per capita fatal accidents at work than countries where this issue is given lower importance (e.g. Czech Republic, Lithuania). However, 
other factors seem to be at play, including the aforementioned degree of satisfaction with life as a whole and the working conditions dimensions discussed in the following paragraph.

The greatest absolute value of correlation found in the study was 0.879 between uncertainty avoidance and people's perceived helpfulness. Hence, people from countries with a low degree of uncertainty avoidance (e.g. Denmark, Sweden, Norway) are bound to perceive others as helpful, while people from countries with a high degree of uncertainty avoidance (e.g. Portugal, Belgium) are bound to perceive others around them as mostly looking out for themselves.

National dimensions of culture that were shown to be strongly associated to physical exposures were uncertainty avoidance and indulgence versus restraint. More tiring and painful positions on average were associated to higher uncertainty avoidance cultures, and relatively high indulgence cultures (e.g. Sweden, Denmark, Great Britain) were on average associated with lower exposure to vibrations from hand tools and machinery and more work with computers than high restraint cultures (e.g. Estonia, Czech Republic). Higher uncertainty avoidance cultures were associated to greater perceived difficulty in finding a new job, while relatively higher indulgent cultures associated to higher perception of work recognition, relationship with colleagues and organization motivated performance and lower prospects of job loss than restraining cultures.

Associations of physical exposures with seIf-perceived health were negative for vibrations, breathing in some and fumes, experiencing tiring or painful positions and performing repetitive hand or arm movements. Job security correlated very notably with trust in the legal system and recognition for work.

Analysis of correlation between fatal accidents at work and physical job exposures yielded a moderate correlation for vibrations from hand tools and machinery, indicating that countries where on average more people are subjected to this physical exposure at work (e.g. Poland, Hungary, Estonia) show a moderate tendency to suffer a relatively higher rate of fatal accidents per capita. The single psychosocial factor that correlated with accidents at work was 'getting on better with own children because of having a job' which associated strongly with non-fatal work accidents. Countries where people on average show higher levels of agreement with the aforementioned EWCS survey item (e.g. Slovenia, Ireland, Finland, Norway) tend to have relatively lower per capita rates of non-fatal accidents at work. Associations of physical exposures with self-perceived health were negative for vibrations, breathing in some and fumes, experiencing tiring or painful positions and performing repetitive hand or arm movements. Job security correlated very notably with trust in the legal system and recognition for work. The greatest absolute value of correlation found in the study was 0.879 and it was achieved between job insecurity and trust in the legal system.

Regression results for fatal accidents at work point to satisfaction with life as a whole as the single predictor, when encompassing in the model the social and working conditions variables selected for this study. However, when adding cultural factors to the two aforementioned domains, the results suggest that countries with lower individuality and higher collective national culture (e.g. Slovenia, Portugal) and where at the same time, on average, citizens place relatively higher important on equal treatment and opportunities (e.g. Slovenia) are bound to incur in relatively higher fatal work accident rates per capita. Linear regression of non-fatal work accidents shows a very high determination coefficient on two six variable models. There are four variables common to both models, which are gender imbalance (the more females the less accidents), lifting or moving people (more lifting yields more accidents), importance given to rules (the more disregard for rules the more accidents) and meeting for socializing (the more frequent social gatherings the more accidents at work).

There are limitations in this study. First and foremost, given the breadth of the ESS and ECWS surveys, a selection of variables was made, which carries a level of subjectivity. Moreover, the size of the level of analysis in this study (country level) precludes fine grained differences which are inherently present in any big population group, such as a nation. This notwithstanding strong correlations were found between all the three 
datasets associated in this study. Moreover, the European countries included in each of the three datasets considered was not the same; the intersection of the three datasets yielded a sample of twenty European countries. Hence, the scope of analysis, while continent wide, is not completely encompassing.

\section{CONCLUSION}

The current study was aimed at providing a contribution to the understanding of the association of social and cultural factors and working conditions with fatal and non-fatal accidents at work across Europe. The study shows a moderate strength and quantity of associations of social, cultural and working conditions variables to accidents at work.

The correlation analysis between social and occupational dimensions showed the salience of peoples' perceived helpfulness, subjective general health, peoples' perceived trustworthiness, the trustworthiness of the legal system, the level of satisfaction with life as a whole, experiencing tiring or painful positions, working with electronic devices, recognition for work, organization motivated performance, job insecurity and prospects of finding a new job if needed. The social dimensions that are most noteworthy as determinants of working conditions are peoples' perceived helpfulness, subjective general health, peoples' perceived trustworthiness, the trustworthiness of the legal system, the level of satisfaction with life as a whole. In most countries encompassed in this study, fatal accidents at work are two to three orders of magnitude below non-fatal accidents of work; in many countries there is one fatal work accident for roughly every thousand non-fatal work accidents. Hence, the meager results of association and regression obtained for the fatal work accidents are understandable given that this is in most countries a "residual" phenomenon, where much progress has been made over the last decades. The most consistent determinants of fatal accidents found through the multiple approaches of association deployed was satisfaction with life as a whole. Determinants of non-fatal accidents consistently found through multiple approaches of association were relatively lower proportion of females in the population, higher incidence of lifting, propensity to disregard rules and a higher frequency of social gatherings.

When associating cultural dimensions with social dimensions, the more salient dimensions are power distance, uncertainty avoidance, indulgence versus restraint, trust in other people and trust in the legal system. Associating cultural dimensions with working conditions sheds light on the importance of indulgence versus restraint, uncertainty avoidance, 'Handling or being in direct contact with materials which can be infectious, such as waste, bodily fluids, laboratory materials, etc.', 'Tiring or painful positions', job insecurity, recognition for work, ease of working with colleagues and prospects of finding a new job if needed.

Overall, the cultural dimensions that are most important as determinants of working conditions are uncertainty avoidance and indulgence versus restraint. The social dimensions that are most noteworthy as determinants of working conditions are peoples' perceived helpfulness, subjective general health, peoples' perceived trustworthiness, the trustworthiness of the legal system, the level of satisfaction with life as a whole. Of these, perceived helpfulness, subjective general health and the level of satisfaction with life as a whole are those that are not strongly associated to cultural dimensions, and hence, those where it will be easier to set policy measures aiming for improvement that do not have to go against culture, and hence are more likely to succeed.

The cultural dimension of uncertainty avoidance is well-established as a predictor of predispositions to take risk or be risk averse (Sully de Luque \& Javidan, 2004). If trust is the willingness to take risk in a relationship (Schoorman et al., 2007), the results of the current study shed light on how uncertainty avoidance as a dispositional quality affects the onset of trust. This notwithstanding, there is considerable work that needs to be done in fine-tuning what is known about the influence of culture on the propensity to trust. Future research should also focus on different levels of analysis, and exploring further implications for safety policy of the findings of the current study. Moreover, given the existence of longitudinal data for accident data and for the working con- 
ditions and social surveys, it is feasible to explore the evolution of the associations, and as such ascertain their persistence over time, and provide a contribution to build more generalized models of the phenomena under study.

Highlights:

- Satisfaction with life as a whole is the most consistent determinant of fatal accidents at work

- Other factors considered are only moderately associated to fatal occupational accidents

- Lifting, rules disregard and high frequency of social gatherings determine non-fatal accidents

- Cultural uncertainty avoidance and indulgence vs. restraint determine working conditions

- Trust in other people and trust in the legal system are also culturally determined

\section{Acknowledgements}

The author acknowledges support for this research achieved through partial funding from Fundação para a Ciência e a Tecnologia through project UID/EMS/00151/2013 C-MAST. This paper is a revised and expanded version of a paper entitled 'Social, cultural and working conditions determinants of occupational accidents in Europe' presented at $7^{\text {th }}$ International Ergonomics Conference, ERGONOMICS 2018, Zadar, Croatia, 13-16 June 2018.

\section{REFERENCES}

6th EWCS 2015: European Foundation for the Improvement of Living and Working Conditions. Euro-pean Working Conditions Survey, 2015. [data collection]. 3rd Edition. UK Data Service, 2017 [Ac-cessed 01 March 2017]. Available from: http://doi.org/10.5255/UKDA-SN-8098-3

Au, K. Y.: Intra-cultural variation as another construct of international management: a study based on secondary data of 42 countries. J. Int. Manage., 6, pp. 217-238 (2000)
Barata, I.G., Coelho, D.A.: Traffic Fatalities and Serious Injuries in Europe-A study of association with cultural, demographic and income variables. In: Sakae Yamamoto (ed.) Human Interface and the Management of Information, Information and Knowledge in Context - Part II, LNCS 9173, pp. 420-427. Springer, Heidelberg (2015)

Coelho, D. A.: A study on the relation between manufacturing strategy, company size, country culture and product and process innovation in Europe. International Journal of Business and Globalisation, 7(2), pp. 152-165 (2011)

Coelho, D.A.: Association of National Dimensions of Culture with Perceived Public Sector Corruption. In International Conference on Human Interface and the Management of Information (pp. 420-427). Springer International Publishing (2015)

Coelho, D.A.: Cultural and Innovation Shaping of Human Systems Integration Path to Design. In Advances in Human Factors and System Interactions (pp. 25-34). Springer International Publishing (2017)

Coelho, D. A.: Social, cultural and working conditions determinants of occupational accidents in Europe. Book of Proceedings of the 7th International Ergonomics Conference "Ergonomics 2018 - Emphasis on Wellbeing", Sumpor, D. et al. (ed.), Croatian Ergonomics Society, Zagreb, 1-16, 2018.

EUROFOUND: European Working Conditions Surveys (EWCS). Accessed March 1, 2017. https:// www.eurofound.europa.eu/surveys/europeanworking-conditions-surveys (2017)

European Social Survey Round 7 (ESS7) Data: Data file edition 2.1. NSD - Norwegian Centre for Research Data, Norway - Data Archive and distributor of ESS data for ESS ERIC (2014)

EUROSTAT: Demographic Balance. Accessed March 1st 2017, ec.europa.eu/eurostat/statisticsexplained/index.php (2017b)

EUROSTAT: European statistics on accidents at work. Accessed March 1st 2017, ec.europa.eu/ eurostat/statistics-explained/index.php/Accidents_ at_work_statistics (2017) 
Flynn, B. B., Saladin, B.: Relevance of Baldridge constructs in an international context: a study of national culture. J. Oper. Manage., 2006, 24, pp. 583-603 (2006)

Hofstede Centre.: The Hofstede Centre: Strategy - Culture - Change. URL: geerthofstede.com (2015)

Hofstede, G.: Culture's Consequences: Comparing Values, Behaviours, Institutions and Organizations Across Countries. Sage, Thousand Oaks, CA (2001)

Hofstede, G.: Culture's Consequences: International Differences in Work-related Values. Sage, London (1980)

Hofstede, G.: National cultures in four dimensions: A research-based theory of cultural differences among nations. International Studies of Management \& Organization, 13(1/2), 99.46--74 (1983)

Schoorman, F. D., Mayer, R. C., Davis, J. H.: An integrative model of organizational trust: Past, present, and future. Academy of Management review, 32(2), pp. 344--354 (2007)
Snell, R. S., Hui, S. K. K.: Towards the Hong Kong learning organization: an exploratory case study. J. Appl. Manage. Stud., 9 (2), pp. 150-175 (2000)

Sully de Luque, M., Javidan, M.: Uncertainty avoidance. In R. J. House, P. J. Hanges, M. Javidan, P. Dorfman, V. Gupta (Eds.), Culture, leadership and organizations: The GLOBE study of 62 societies, pp. 603-644. Thousand Oaks, CA: Sage (2004)

van Oudenhoven, J. P.: Do organizations reflect national cultures? A 10-nation study, International Journal of Intercultural Relations, 25 (2001), pp.89-107

Vecchi, A., Brennan, L.: A cultural perspective on innovation in international manufacturing, Research in International Business and Finance, 23: pp. 181-192 (2009)

Wacker, J. G., Sprague, L. G.: Forecasting accuracy: comparing the relative effectiveness of practices between seven developed countries. J. Oper. Manage., 16 (2), pp. 271-290 (1998) 


\section{DRUŠTVENI, KULTURNI I RADNI UVJETI KAO DETERMINANTE NESREĆA SA SMRTNIM I NESMRTNIM POSLJEDICAMA U EUROPI}

SAŽETAK: Opisane su determinante nesreća na radu s aspekta društvenih, kulturnih i radnih uvjeta, i to na razini Europe kao naroda. Podatci o nesrećama sa smrtnim i nesmrtnim posljedicama u 2014. godini koje je prikupio Eurostat korelirani su s podatcima pojedinih zemalja 7. Europskog društvenog izvješća (ESS) iz 2014. Izvješće prikazuje društvene determinante nesreća na radu. Nacionalna kulturna obilježja koje je utvrdio Gert Hofstede korelirana su s podatcima pojedinih zemalja utvrđenih ESS-om. Nadalje, korištenjem podataka 6. Europskog izvješća o radnim uvjetima po pojedinim zemljama (podatci iz 2015.) analiziraju se smrtne i nesmrtne nesreće u pojedinim zemljama, a i njihova povezanost s društvenim i kulturnim obilježjima. Ova višestruka studija povezanosti otkriva zanimljivu vezu između smrtnih i nesmrtnih nesreća i društvenih i kulturnih čimbenika te između društvenih i kulturnih čimbenika i radnih uvjeta, uzimajući pojedinu europsku zemlju kao jedinicu analize. Rezultati pokazuju međusobnu povezanost područja proučavanih u studiji te usmjeravaju razvoj politika posebno definiranih za svaku pojedinu zemlju.

Ključne riječi: društveni čimbenici, kultura, zaštita na radu, nesreće na radu, međunarodna analiza

Izvorni znanstveni rad

Primljeno: 4.6.2019.

Prihvaćeno: 2.3.2020. 